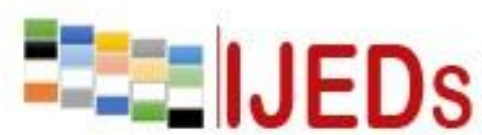

http://ijeds.ppj.unp.ac.id/index.php/IJEDS

\title{
The Symbolic Meaning of the Tradition "Hantaran Jamba Badagang" in a Wedding Party Ceremony at Kambang Lengayang sub-district, Pesisir Selatan
}

\author{
* Mega Silvia Nengsih ${ }^{1}$, Syafwandi ${ }^{2}$ \\ ${ }^{1}$ Master's Program, Postgraduate, Faculty of Social Scinse, Art and culture, Universitas \\ Negeri Padang, Indonesia \\ ${ }^{2}$ Lecturer Doctoral Program, Postgraduate, Faculty of Social Scinse, Art and culture, \\ Universitas Negeri Padang, Indonesia \\ Email: syafwandi1960@fbs.unp.ac.id
}

*Corresponding Author, Received: November 12, 2019, Revised: December 10, 2019, Accepted: December 21, 2019

\begin{abstract}
This article aims to describe the shape and meaning of symbols on the delivery of Jamba Badagang in a wedding party ceremony. The approach used to parse the results of this research were the approach of art, culture, semiotics and aesthetics. The research method used descriptive qualitative. Data collection done by Observation (documentation) and Interview (Interview). Data analysis techniques used Miles and Huberman data analysis models, namely data collection, data reduction, data presentation, and drawing conclusions. The results showed that the tradition of the Hantaran Jamba Badagang was a symbol of interaction, communication, and social value. This tradition also contains the meaning of unity between communities and educational values. Furthermore, the Jamba Badagang tradition continues to be preserve and develope into the cultural heritage of the Kambang nagari community.
\end{abstract}

Keywords : Tradition, Culture, Form, Meaning, Symbol

\section{INTRODUCTION}

Minangkabau is one of the ethnic groups in Indonesia, which has a variety of unique and diverse cultures. Minangkabau is one of the tribes in the archipelago which is better known as the Minang tribe. This tribe known as a tribe that represents the area of West Sumatra. West Sumatra has many areas, one of which is nagari Kambang, nagari Kambang located in Lengayang Subdistrict, Pesisir Selatan Regency, West Sumatra. The people in nagari Kambang regulated by culture and they cannot be 


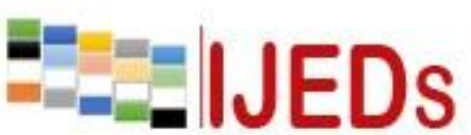

http://ijeds.ppj.unp.ac.id/index.php/IJEDS
International Journal of Educational Dynamics

Vol. 2 No. 1 (pp. 99-112) Desember 2019

p_ISSN 2655-4852

e_ISSN 2655-5093

separated from culture, where the culture bridge the activities of the community and its environment. Therefore, the culture lives and grows in the Kambang community must be nurtured and developed in order to realize the cultural elements.

One element of culture is the kindship system of how humans shape society as a social group. Every human being governed by the customs and rules that apply in society. The customs that govern people's attitudes and life patterns have been passed down by the previous generation (ancestors) to the next generation. In addition there is a close relationship with the value system contained a very valuable heritage for the community.

Customs in Minangkabau consist of nan sabana adat customs, nan diadatkan customs, nan teradatcustoms and istiadat customs. These four customs have their own rules in life. The law of nan sabana adat custom and nan diadatkancustom are babuhua mati, which means that it cannot be changed even with consensus. Whereas teradat custom and istiadat custom are babuhua sentak, which means that they can be changed from origin to through consensus. the four types of customs are a unity that cannot be separated from one to another, wholly called the custom of the Minangkabau.

Istiadat customs are rules that also made by the princes (also called penghulu) in a village by means of consensus relating to the preferences of the village children such as art, sports, nagari children's games, men's clothing, women's clothing, luggage belonging to the bride's house and so on. Likewise marawa, jellyfish, ladder, grain, the bridal couple sits and so on that vary in each village. So according to the saying that reads " Lain lubuak lain ikannyo, lain padang lain balalangnyo, lain nagari lain adatnyo (its customs)". It explain that each nagari has its own characteristics that will become the identity of a nagari.

One of them is the culture in Kambang fences, namely the tradition in the wedding ceremony that carried out in Kambang fences, known as the Hantaran Jamba Badagang tradition. Jamba Badagang is one of the traditions of Kambang folklore which carried out at a mamak's children's wedding and to honor mamak, the nephew gives a delivery called Jamba Badagang. Mamak and nephew can be interpreted in general and specifically. In particular Mamak is a brother of the mother while in general mamak is a man of the same tribe with the mother. In particular the nephew is the 


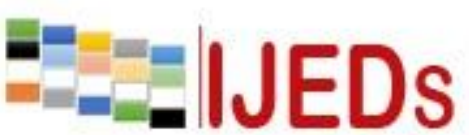

http://ijeds.ppj.unp.ac.id/index.php/IJEDS
International Journal of Educational Dynamics

Vol. 2 No. 1 (pp. 99-112) Desember 2019

p_ISSN 2655-4852

e_ISSN 2655-5093

daughter of a sister. Generally, the nephew is one tribe with mother. Marriages in Bugis community always give the authority toolder person to direct during ritual processes [1]. This means appreciation and hopethat the marriage is running well are the factors [1]. This research is included in naturalistic research which is intendedto explore the wedding ritual in Pekalongan, a town in the north part ofCentral Java which has a special characteristic [2].

The Hantaran Jamba Badagang tradition has been handed down from the past which has become a habit of generations to generations until now, although it has changed but does not eliminate its authenticity. Hantaran Jamba Badagang is a custom that applies in the Kambang village which has a very close relationship with the value system found in the Kambang village community. If this tradition is not implemented then there will be a perception that customes no longer applies to nagari Kambang .

The existence of Jamba Badagang is a visual form that is still used until today. Jamba Badagang has the characteristic and unique shape of the stretcher. Jamba Badagang has not been found in other areas in West Sumatra. Thus the Jamba Badagang is not only an object that used in custome but also as a custom symbol of the Kambang village. Hantaran Jamba Badagang is a symbol of the position of a mamak in a people. With the existence of Hantaran Jamba Badagang is a form of appreciation given to mamak for the performance carried out, ranging from maintaining and handling any problems that occur in his people. In addition to the meaning contained in the Hantaran Jamba Badagang in outline, there are meanings contain the parts in the Jamba Badagang.

An early observations on January 13th, 2019, the writer with Ibu Yunas (65 years old) at her residence, said that Hantaran Jamba Badagang has exist since the past, which was a hereditary habit in the Kambang fences. The Hantaran Jamba Badagang tradition is a tradition that only exists in Lengayang Subdistrict, Pesisir Selatan Regency. Hantaran Jamba Badagang is an object that represents the respect that given to mamak who has functioned in his people. Besides this tradition has a very important meaning for the nagari Kambang community, both in terms of the purpose of giving and the meanings contained there. Furthermore, the Hantaran Jamba Badagang tradition can establish friendship in the community and foster a strong sense of principle, and 


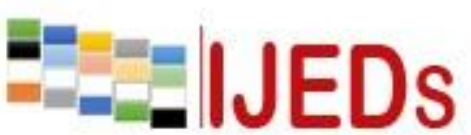

http://ijeds.ppj.unp.ac.id/index.php/IJEDS
International Journal of Educational Dynamics

Vol. 2 No. 1 (pp. 99-112) Desember 2019

p_ISSN 2655-4852

e_ISSN 2655-5093

friendship between people.. While symbols are objects that have implied meanings and intentions [3]. The result of research showed that symbolic situation of Serah-serahan in traditional Javanese wedding ceremony Desa Tanjung Belit Kecamatan Siak Kecil Kabupaten Bengkalis Province Riau include physical objects such as pisang sanggan, suruh ayu, cincin, seperangkat busana putri, traditional meal, and some money and the social objects from the Serah-serahan in traditional Javanese wedding ceremony include all the procession of Javanese wedding ceremony. In the Serah-serahan contained the social value and culture value [4].

Wedding gift is given in three steps. They are on prewedding step, that is at engagement, consists of prayer equipment and some foods from the woman which have meaning in order to her fiance always pray frequently while some foods have meaning together each other [5]. Tradition comes from the Latin Tradition which says basic trodere, means to hand over, to continue from generation to generation. Tradition is something that has been done for a long time and it is a part of the life of a group of people or hereditary habits that are still practiced by the community.. Tradition is a process of continuity, because tradition is often referred to as a habit that lives in human life. In addition, tradition contains events, values, morals, religions, customs, imaginary stories and songs. In addition, tradition is also a legacy of values that considere good and relevant to the needs of society from time to time. Inheritance of values in the next generation is very necessary so that they can understand and preserve it.

Furthermore, the writer conducted an interview with Mr. Isar (73 years old) in his residence, stating that the Hantaran Jamba Badagang is a custom of the Kambang folklore which has been passed down from generations of generation to the present. This tradition is a custom that prevails in Lengayang Subdistrict, Pesisir Selatan Regency. With the tradition of Hantaran Jamba Badagang generally symbolizes the position of a mamak by giving an award that is Jamba Badagang. In addition, there are also symbols that attach to Jamba Badagang which contain meaning and understanding by the Kambang villagers.

Then it can be conclude that the tradition of the Hantaran Jamba Badagang is a tradition that found in the fencing of Kambang Lengayang Subdistrict, Pesisir Selatan Regency which still survives to this day, although it has changed but does not eliminate 


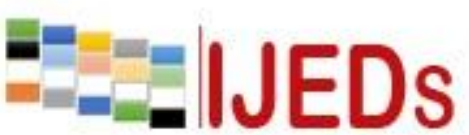

http://ijeds.ppj.unp.ac.id/index.php/IJEDS
International Journal of Educational Dynamics

Vol. 2 No. 1 (pp. 99-112) Desember 2019

p_ISSN 2655-4852

e_ISSN 2655-5093

its authenticity. This tradition is very important for the people of Kambang village because it has a very close relationship with the value system contained in the Kambang village. In addition, Hantaran Jamba Badagang became a symbol for the Kambang nagari community for their mamak position. Symbols on the delivery of the Jamba Badagang are not only on the purpose of giving the Jamba Badagang, but there also important for the Kambang nagari community.

Symbols are objects that implied meanings and intentions. This wedding is symbolized by slaughtering a buffalo and a long speech or pidato panjang. The cloth worn by the groom is called Marapulai indak babaju or Marapulai basanda kain barangkok [6]. This cloth surely has unique characteristics and implied values derived from its uniqueness The shape of the symbol is not only in the form of visible objects but also through movement and speech. Symbols can be used to interact for the process of conveying intentions and messages to others. So that the symbol can be a communication medium in interacting both through objects, gestures and speech. Where symbols are languages that are mutually agreed upon

Furthermore, the sign can be seen as a meaning that describes a work [7]. The meaning is a representation as a knowledge in the process of recording ideas and messages physically [8]. Moreover, it can be define as the use of "signs" (pictures, sounds, etc.) to re-display something that absorbed by the senses, imagined or felt in physical form. The use of signs is the concept of thought of people who use the sign and reduce it to a certain meaning that is in someone's mind about the object to which a sign is referred.

The Hantaran Jamba Badagang is a tradition of the Kambang folklore inherited from generation to generation. This culture can continue to survive because the habits of the Kambang nagari community are still being carried out. So the meaning will remain if the culture and habits do not change.

\section{METHOD}

This research used a qualitative method with the type of descriptive research, producing data in the form of words and images [9]. Research on the tradition of Hantaran Jamba Badagang in a wedding ceremony at Kambang Lengayang Subdistrict, South Pesisir Regency tried to describe a phenomenon / event systematically in 


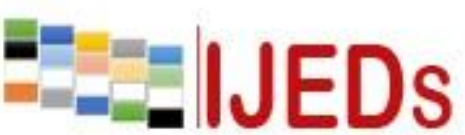

http://ijeds.ppj.unp.ac.id/index.php/IJEDS
International Journal of Educational Dynamics

Vol. 2 No. 1 (pp. 99-112) Desember 2019

p_ISSN 2655-4852

e_ISSN 2655-5093

accordance with what it is. The qualitative approach describes a phenomenon about the environment and social life in society. Furthermore, the qualitative method is also a naturalistic method because the research conducted is still natural. The location of this research conducted in Kambang, Lengayang Subdistrict, Pesisir Selatan Regency. When the research was conducted at a wedding. The reason for taking the research here because the area is a researchers village and also the researcher wants to analyze the tradition of Hantaran Jamba Badagang in a wedding at Kambang Lengayang Subdistrict, Pesisir Selatan Regency.

The researcher chose Mr. Syarkani Mandaro Kayo as the initial key informant, because he was a traditional mamak who participated in deciding whether or not the tradition of the Hantaran Jamba Badagang performed at a wedding. Then, from that information, the other informants were obtained, according to the data and information that the researcher also wanted to find with the problem to be examined.

This research used descriptive qualitative method that used for problems related to the process of community life, especially those related to customs, artistic phenomena that involve community behavior which is the subject of research in treating cultural objects. Data collection techniques in this research were literature review, observation, interview and documentation. The data validity technique used techniques to extend participation, persistence of observation and triangulation. Data analysis techniques based on Miles and Huberman [10] which related components as follows: data collection, data reduction, data presentation and drawing conclusions.

\section{RESULTS AND DISCUSSION}

\section{The Tradition of Hantaran Jamba Badagang in a wedding ceremony at Kambang area.}

Nagari Kambang established around 500 years after the agreement of four people, Sultan Califah, Sultan Ibrahim, Mandaro Padang, and Sulaiman. These four people are known as "Bijo dimalayu ampek niniak, parik paga sutan jo bagindo". Since the Kambang nagari established, custom has been in effect and developed into istiadat customs. Many kinds of customs in Kambang fenced by one of them are the Hantaran Jamba Badagang tradition which carried out at certain times, such as at weddings, batagak gala (appointment titles), balimau events and so on. 


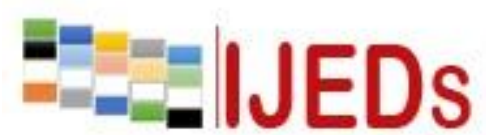

http://ijeds.ppj.unp.ac.id/index.php/IJEDS
International Journal of Educational Dynamics

Vol. 2 No. 1 (pp. 99-112) Desember 2019

p_ISSN 2655-4852

e_ISSN 2655-5093

Hantaran Jamba Badagang is one of the traditions of the people in Kambang area which performed at a mamak children's wedding and to honor mamak, the nephew gives a delivery called Jamba Badagang. Named Hantaran Jamba Badagang because Jamba brought by the way in Commerce which means appointed. The person to appoint the Hantaran Jamba Badagang is a nephew of four who may not be less or more and accompanied by mamak.

The Tradition of Hantaran Jamba Badagang began to glorify the mamak who plays a role in a people. Starting from guiding the nephew of all things such as customs, religion, and daily behavior. Furthermore mamak is a messenger from the family who resolves all matters both from inside and outside, Mamak will represent in the family. Based on the agreement between mamak and nephew, to give glory and appreciation for mamak, a delivery called Hantaran Jamba Badagang.

Hantaran Jamba Badagang has a unique shape and different from other Jamba. This servant is in the form of a box by carrying it in the trade (appointed). It has decorations that have the meaning of the symbols attached to the Jamba Badagang. In addition there are also contents that gifts from mamak and nephew for mamak who is holding a wedding for their children. Jamba Badagang arise not because of the rules of a custom but was the ideas of the founders of the Kambang nagari and it agreed by the community on how to glorify the mamak who had a very large role in the family. Besides, when someone deliver Jamba Badagang to the mamak's house holding who celebrate his son's wedding party,Jamba Badagang accompanied by Gandang Sarunai to make the occasion more fun when Jamba Badagang delivered to the mamak's house who celebrated his child's wedding party.

\section{The symbol and meaning of the Hantaran Jamba Badagang tradition}

There are many symbols in Kambang, one of them is the symbol that found in the Hantaran Jamba Badagang at the wedding party. The symbols contained in the Hantaran Jamba Badagang are not only on the delivery of the Jantaran course, but also a symbols and meanings of the components present in Jamba Badagang. Both in terms of form, the object used and the contents of Jamba.

That is mean, the occurrence of the tradition Hantaran Jamba Badagang is a way to glorify a mamak who had a very large role in the family and people by giving a 


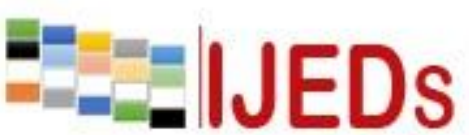

http://ijeds.ppj.unp.ac.id/index.php/IJEDS
International Journal of Educational Dynamics

Vol. 2 No. 1 (pp. 99-112) Desember 2019

p_ISSN 2655-4852

e_ISSN 2655-5093

delivery called the Hantaran Jamba Badagang. In addition to the meaning of the Hantaran Jamba Badagang, there is also a symbolic meaning on the Hantaran Jamba Badagang.

Hantaran Jamba Badagang consists of the form of the jamba, tonggak jamba, Langan Panjang, Sumarak Jamba, Bungo Jamba, Kain Panjang Nan Bajulai, Talingo Jamba, Sarawa Jamba, Isi Jamba, and Kain Nan Bakanyam. The parts of the Hantaran Jamba Badagang is a symbol which found on the Jamba Badagang that still intact since before.

\section{The Procession of Hantaran Jamba Badagang in the wedding ceremony.}

The tradition in the Kambang area is very diverse, one of them is the tradition in the wedding ceremony that called Hantaran Jamba Badagang. The Hantaran Jamba Badagang tradition is unique which is characteristics of Kambang area. The uniqueness of this tradition can be seen from the form, procession and meaning to be conveyed both in terms of objectives and symbols contained in Hantaran Jamba Badagang. The procession of the Hantaran Jamba Badagang is not the same with the other Jamba, but it has certain conditions that must be met so that the occurrence of the Hantaran Jamba Badagang. The handover of the Jamba Badagang does not occur throughout Minangkabau, but only in Lengayang Subdistrict, Pesisir Selatan Regency, one of it is in Kambang.

The implementation of the Hantaran Jamba Badagang tradition cannot be separate from deliberation and consensus. This ingrained for the people in Minangkabau who always deliberate when they are going to do an activity that involves a lot of people so that there is solidarity between people. In accordance with the proverb in Minangkabau which is " berat sama dipikul, ringan sama dijinjing " that has a meaning : a work that will be light if we done together.

The beginning of this tradition done by gathering together at the house of one of the nephews who agreed to talk about the Hantaran Jamba Badagang. The victory invited mamak or known as maucok. Maucok is an invitation submitted to attend an agreed meeting or association in order to reach consensus. This gathering called coffee drinking, this is because the mamak and nephew gather to talk about the Jamba Badagang delivery while drinking a coffee. 


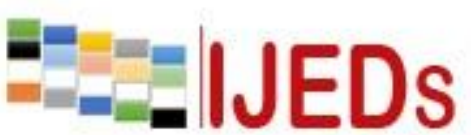

http://ijeds.ppj.unp.ac.id/index.php/IJEDS
International Journal of Educational Dynamics

Vol. 2 No. 1 (pp. 99-112) Desember 2019

p_ISSN 2655-4852

e_ISSN 2655-5093

Along with the time, drinking coffee at first was usually done several times, but nowadays drinking coffee done only once or twice. It happened because mamak and nephew want to minimize the time needed to deliberate about Hantaran Jamba Badagang. In addition, it also minimize expenses incurred during drinking coffee, so that it is more practical. The time of this coffee drinking event will be discuss all related to the implementation of the Hantaran Jamba Badagang from start to finish until the contents that will be given for the tradition of Hantaran Jamba Badagang.

The results of deliberations or drinking coffee include the preparation of Jamba Badagang complete with the attributes that attached to the Jamba Badagang, the content agreement given, the time of delivery, the person who will bring the Jamba Badagang, and the accompaniment of the Jamba Badagang. Furthermore, after obtaining the results of drinking coffee it will be continue with the implementation of Hantaran Jamba Badagang. Furthermore, after Jamba Badagang prepare completely with all the attributes, the contents of the jamba as well as giving mamak and nephew to the mamak who celebrate his child's wedding. After everything is ready, then Hantaran Jamba Badagang ushere together to the mamak's house that is holding his child's wedding. The time to deliver the Jamba Badagang is usually done after the noon, this is in accordance with the agreement that reach during the coffee drink.

The person who pick up the Hantaran Jamba Badagang is a nephew and he or she is accompany by other mamak. In addition, this Hantaran Jamba Badagang is not only accompany by mamak and nephew, but also accompany by a Gandang sarunai. Gandang sarunai is a musical instrument that play to accompany Jamba Badagang by using the gandang and sarunai musical instruments. It use to make Hantaran Jamba Badagang more fun when deliver it to the mamak's house who hold his child's wedding party.

Arriving at the house of the mamak who had a party, the arrival welcome by mamak who came from the wife of the mamak who hold a wedding for her child, because the one who came to the mamak had to be welcomed by the mamak too. After Hantaran Jamba Badagang receive by mamak, it is immediately open and issue one by one. If the contents of Hantaran Jamba Badgang contain with gold, it is immediately 


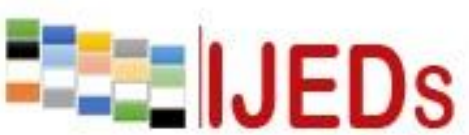

http://ijeds.ppj.unp.ac.id/index.php/IJEDS
International Journal of Educational Dynamics

Vol. 2 No. 1 (pp. 99-112) Desember 2019

p_ISSN 2655-4852

e_ISSN 2655-5093

apply to the child who became the bride. If it is a money, it give to the mamak who had a wedding to help ease the burden on the mamak.

Furthermore, the group deliver Hantaran jamba badgang treat with food and drink, it is not just for relieving hunger and thirst but also a symbol to honor guests who came. After finish to enjoy the banquet give by the mamak's family who hold his child's party, the whole group that deliver Hantaran Jamba Badagang give their congratulations to the bride and groom to take leave. Then the tradition of Hantaran Jamba Badagang is done.

\section{Hantaran Jamba Badagang in the wedding party for nagari Kambang's villagers.}

Hantaran Jamba Badagang is a tradition that has been carried out by the nagari Kambang since the nagari Kambang was established. Hantaran Jamba Badagang becomes a necessity, this is because the tradition is a characteristic of nagari Kambang. If this tradition is not carry out then an assumption arises that adat no longer applies in Kambang. Hantaran Jamba Badagang is only available in Lengayang District, one of which is in Kambang.

The people in Kambang are people who are still thick with the customs. This happened since Nagari Kambang established until now. As time pst by there is a renewal, but this does not change the intent and purpose to be conveyed. Changes that occur only in the process before carrying out the tradition of Hantaran Jamba Badagang. Usually deliberations undertaken to reach an agreement to conduct Hantaran Jamba Badagang require repeated deliberations to reach an agreement, but this is no longer the case because the community will conduct one or two meetings.

The tradition of Hantaran Jamba Badagang has meaning, both from the purpose in holding the tradition of Hantaran Jamba Badagang and the attributes that attach to Hantaran Jamba Badagang. The symbol contain in Hantaran Jamba Badagang is the intention to be express through an object that has become a mutual agreement. This symbol has become a substitute for custom expressions that contain certain meanings and intentions regarding Hantaran jamba badagang for Kambang people. 


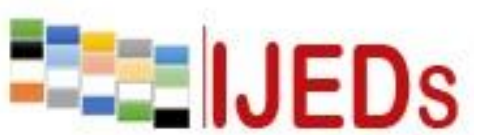

http://ijeds.ppj.unp.ac.id/index.php/IJEDS
International Journal of Educational Dynamics

Vol. 2 No. 1 (pp. 99-112) Desember 2019

p_ISSN 2655-4852

e_ISSN 2655-5093

The people in nagari Kambang are still preserving the Hantaran Jamba Badagang tradition, because Hantaran Jamba Badagang is one of the customs that still applies today. Hantaran Jamba Badagang has been very beneficial for the people of nagari Kambang. The benefits of Jamba Badagang are not only to respect and glorify Mamak who has a role in a people, but also seen the cohesiveness in a tribe and the existence of a sense of help in community life.

To glorify mamak by giving Hantaran Jamba Badagang when the mamak holds a wedding for his child, this symbolizes the position and role of a mamak in his people. If a mamak has a wedding for his child, there is no Hantaran Jamba Badagang, then the mamak is not valued by her nephew and other mums. Vice versa, if the mamak holds a wedding for his son there is Hantaran Jamba Badagang, then the mamak has an important position in his people so that his nephews and other mamak respect and glorify him by giving a conduct called Jamba Badagang.

In addition to the symbol of the position of mamak, Hantaran Jamba Badagang also contains the principle of help. This can be seen that Hantaran Jamba Badagang is not only given, but there is also content given to mamak. The contents of Jamba Badagang's conveyance are not only in the form of objects and food, but also in the form of money or gold. Thus it is seen that there is also material assistance that will ease the burden of the mamak who is holding his child's wedding.

Based on the description above the Hantaran Jamba Badagang is very important for the nagari Kambang, this is also one of the reasons that tradition is still ongoing today. The Tradition of Hantaran Jamba Badagang upholds the way of life in Minangkabau especially the Kambang nagari to copy respect and help each other in community life.

\section{CONCLUSION}

Badagang is one of the traditions that still exist in nagari Kambang until now. The Hantaran Jamba Badagang tradition is also one of the cultural focuses which recognized as a cultural custom by the nagari Kambang. Besides this tradition has meaning and value it is important for the nagari Kambang community. Hantaran Jamba Badagang is a way to respect mamak by giving an award in the form of Hantaran called Jamba Badagang. This delivery becomes a symbol of the position of mamak in a 


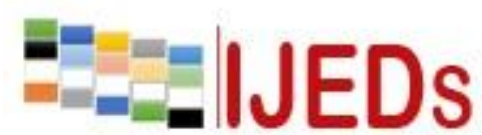

http://ijeds.ppj.unp.ac.id/index.php/IJEDS
International Journal of Educational Dynamics

Vol. 2 No. 1 (pp. 99-112) Desember 2019

p_ISSN 2655-4852

e_ISSN 2655-5093

comprehensive, meaningful way and wrap by the prevailing customs in society. In addition to the outline symbol of Jamba Badagang in outline, there are also symbols that found on Jamba Badagang which are the languages and characteristics of the Kambang fenced community.

\section{The origin of Hantaran Jamba Badagang in a wedding ceremony at Kambang}

\section{Lengayang Subdistrict, Pesisir Selatan Regency}

Hantaran Jamba Badagang began because of a kinship in Minangkabau, which is between mamak and nephew. Mamak and nephew are closely related because they have a relationship as led and people are led. Mamak is an institution that takes care of everything related to his people, both in terms of maintaining and completing all the affairs in his people. Based on the great role of mamak against his people, that is why people give an award to him in the form of delivery, namely Jamba Badagang. Mamak who has a wife or is known by the name of tingga dirumah gadang, if mamak holds a wedding for his child, then he is given the delivery of Jamba Badagang by his nephew. This delivery aims to respect and glorify mamak for the performance given to his people.

\section{The tradition of Hantaran Jamba Badagang in a wedding ceremony at}

\section{Kambang Lengayang Subdistrict, Pesisir Selatan Regency}

Hantaran Jamba Badagang is one of the traditions in Kambang fenced at the wedding. This tradition is a form of respect for mamak for all the responsibilities that he carries towards his people. This includes maintaining and completing all matters both inside and outside the home. Furthermore, the Hantaran Jamba Badagang tradition is a tradition that has been going on since the nagari Kambang was established. The Tradition of Jamba Badagang inherited from the past which has maintained its authenticity even though it has undergone several changes, but does not eliminate the values contained therein. This tradition only occurs in the Lengayang District, one of which is in the nagari Kambang.

3. The symbol and meaning of the Hantaran Jamba Badagang tradition in a wedding ceremony at Kambang Lengayang Subdistrict, Pesisir Selatan Regency 


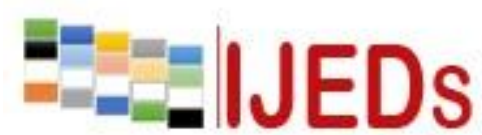

http://ijeds.ppj.unp.ac.id/index.php/IJEDS
International Journal of Educational Dynamics

Vol. 2 No. 1 (pp. 99-112) Desember 2019

p_ISSN 2655-4852

e_ISSN 2655-5093

The Tradition of Hantaran Jamba Badagang related to the existing value system in nagari Kambang. If this tradition does not carry out and if the assumption arises that custom is no longer valid fenced by Kambang. Hantaran Jamba Badagang has a meaning as a symbol of respect for the mamak who has contributed and has a very big role in the family, then he given an award called the Jamba Badagang. In addition there are also meanings contain in Hantaran Jamba Badagang, seen in the items attached to Jamba Badagang. symbols and meanings contain in Jamba Badagang are figures of speech which become the language for communication in nagari Kambang. the parts of the Hantaran Jamba Badagang consist of the form of the Jamba, Langan Panjang, Sumarak Jamba, Bungo Jamba, Kain Panjang Nan Bajulai, Talingo Jamba, Sarawa Jamba, Isi Jamba, and Kain Nan Bakanyam which have their own meanings.

\section{The procession of the Hantaran Jamba Badagang tradition in a wedding ceremony at Kambang Lengayang Subdistrict, Pesisir Selatan Regency}

The process of delivering Jamba badagang begins with deliberation and consensus to reach an agreement. When people have a meeting in that area, so mamak must be invited, this invitation is known as Maucok. The deliberations and consensus programs are known as drinking coffee. This coffee drinking event produced three conclusions, namely 1) planning of the Jamba Badagang Commander; 2) preparation for Delivery of the Jamba Badagang; 3) the implementation of the Jamba Badagang. In the planning moment, it will be decide the contents of the Jamba that will be given to the mamak who is holding his child's wedding party. Then proceed with the preparations that will be made to conduct Hantaran Jamba Badagang. this includes the Jamba badagang complete with all the attributes attached to the Jamba Badagang as well as the agreed contents. Furthermore, it was delivered together to mamak's house.

\section{Hantaran Jamba Badagang at a wedding for the nagari Kambang community.}

Hantaran Jamba Badagang is one of the customs which is still valid until today. Hantaran Jamba Badagang has been very beneficial for the people of nagari Kambang. The benefits of Jamba Badagang are not only to respect and glorify Mamak who has a role in a people, but also seen the cohesiveness in a tribe and the existence of a sense of 


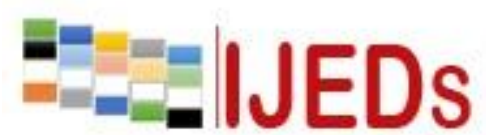

http://ijeds.ppj.unp.ac.id/index.php/IJEDS
International Journal of Educational Dynamics

Vol. 2 No. 1 (pp. 99-112) Desember 2019

p_ISSN 2655-4852

e_ISSN 2655-5093

help in community life. Besides that, the tradition of Hantaran Jamba Badagang is a characteristic of Kambang nagari because this tradition only occurs in Lengayang District. This tradition has important social values to be preserved and hereditary to the next generation.

\section{REFERENCES}

Bungin, Burhan. 2010. Analisis Data Penelitian Kualitatif. Jakarta : Rajagrafindo Danesi, Marcel. (2010). Pesan, Tanda, dan Makna. Yogyakarta: Jalasutra

Hasanah, N., Efi, A., \& Daryusti, D. (2019, March). The Symbolic Meaning of The Bridal Attire on Alek Gulai Manih Marriage in Solok. In Seventh International Conference on Languages and Arts (ICLA 2018). Atlantis Press.

Maknun, M. L. (2013). Tradisi Pernikahan Islam Jawa Pesisir. IBDA: Jurnal Kajian Islam dan Budaya, 11(1), 119-130.

Salam, N. E., \& Windyarti, R. (2015). Makna Simbolik Serah-serahan dalam Upacara Perkawinan Adat Jawa di Desa Tanjung Belit Kecamatan Siak Kecil Kabupaten Bengkalis Provinsi Riau. Jurnal Online Mahasiswa Fakultas Ilmu Sosial dan Ilmu Politik Universitas Riau, 2(2).

Srimutia. Elpalin. (2013). Bentuk, Makna, dan Nilai Filosofi Pakaian Adat Panghulu Dan Bundo Kanduang di Batipuah Baruah Tanah Datar. Tesis

Sugiyono. 2012. Memahami Penelitian Kualitatif. Bandung: Alfabeta

Sugiyono. 2010. Metode Penelitian Pendidikan Pendekatan Kuantitatif, Kualitatif, dan $R \& D$. Bandung: Alfabeta

Wekke, I. S. (2014). Islam dan Adat dalam Pernikahan Masyarakat Bugis di Papua Barat. THAQAFIYYAT: Jurnal Bahasa, Peradaban dan Informasi Islam, 13(2).

Winona, I. R., \& Faidah, M. (2013). Tata Upacara Perkawinan dan Hantaran Pengantin Bekasri Lamongan. Jurnal Tata Rias, 2(02). 